\title{
Timberline tree-ring statistics examined through chronology stripping
}

\author{
Mauri Timonen $^{1^{*}}$, Kari Mielikäinen $^{2}$ and Samuli Helama ${ }^{3}$
}

Timonen, M., Mielikäinen, K., Helama, S. 2012. Timberline tree-ring statistics examined through chronology stripping. - Forestry Studies | Metsanduslikud Uurimused 56, 5-15. ISSN 1406-9954.

\begin{abstract}
Tree-ring data is commonly used in forest science and dendrochronology. As the collected datasets represent restricted populations of theoretical infinite sample size, an interesting question deals with the sample selection that is carried out during the fieldwork and through the data analyses. This paper considers the latter issue, by statistically examining a recently completed Scots pine dataset of timberline tree-rings from Lapland (northern Finland). Following the detrending of individual ring-width series, the composition of the data was restricted using a pre-determined criteria of linear correlativity between the individual sample series and the master chronology $\left(R_{\text {master }}\right)$. This procedure reduced both the number of sites and the sample size (i.e. the number of individual tree-ring series) and altered the tree-ring statistics of the remaining subset of the data in a systematic fashion. It was seen that the first-order autocorrelation, mean sensitivity and standard deviation all ascended with the uplifted $R_{\text {master }}$ criterion. Conspicuously, such filtering also reduced the correlation between the resulting tree-ring chronology and climate parameter. The results indicated that the screening of the data will alter the chronology statistics in a way that may be artificially generated, irrelative to the predetermined sample selection criteria. We remain to assume that the most fundamental selection of data is attained through the cross-dating process.
\end{abstract}

Key words: dendrochronology, dendroclimatology, forest research, Lapland, tree growth, Scots pine.

Authors' addresses: ${ }^{1}$ Finnish Forest Research Institute, P.O. Box 16, 96301 Rovaniemi, Finland, e-mail: mauri.timonen@metla.fi; ${ }^{2}$ Finnish Forest Research Institute, P.O. Box 18, 01301 Vantaa, Finland, e-mail: kari.mielikainen@metla.fi; ${ }^{3}$ Finnish Forest Research Institute, P.O. Box 16, 96301 Rovaniemi, Finland, e-mail: samuli.helama@metla.fi

\section{Introduction}

Tree-rings provide information of radial stem growth making tree-ring research an essential component of forest science (Spiecker, 2002). Importantly, the cross-dating procedure, where the wide and narrow rings are synchronized ring by ring (Douglass, 1941; Yamaguchi, 1991), ensures the exactness of the growth data in temporal domain and enables the construction of mean chronologies (Cook et al., 1990). The tree-ring chronologies contain less uncertainty about the overall growth variability
(Fritts, 1976) and the chronologies of ringwidths are direct sources of data and historical information on forest growth on annual basis (Biondi, 1999; Metsaranta \& Lieffers, 2009).

Actually, it has become relatively uncommon to study individual sample series of ring-widths. Instead, the bulk of studies directly use the mean tree-ring as an exclusive growth estimate. Interestingly, a recent study (Carrer, 2011) showed how the information of individual tree-ring 
series may be used to improve the quality and reliability of the inferences derived from large sets of tree-ring material. The essence of this idea, i.e. using the individual trees rather than the mean of available samples, stems from the attention of researchers to select the most promising sites and trees for the analysis (Carrer, 2011). During the fieldwork, this is done according to the sampling strategies (LaMarche, 1982; Phipps, 1982; Schweingruber, 1990), with an aim to collect the tree-ring material to test the prevailing hypothesis. Subsequent selection might proceed through the selection of data, by evaluating the time-series from individual trees. The most fundamental filtering of data is attained by accepting the sample series into the chronology through cross-dating process but the treering data can be additionally screened by different statistical methods (Peters et al., 1981; Riitters, 1990; Fowler \& Boswijk, 2003; Carrer, 2011). These methods alter the composition of data by hypothetically crystallizing the signal and reducing amount of the noise (i.e., the unwanted growth variations) in the resulting chronology.

In northern Finland, the tree-rings of Scots pine have frequently been studied using varying hypotheses and differently collected materials. Tree-rings near the timberline in Finnish Lapland have been used for estimations of growth trends and thinning responses (Mielikäinen \& Timonen, 1996; Varmola et al., 2004; Helama et al., 2008), to statistically model the growth characteristics (Mikola, 1950; Linholm et al., 2000; Helama et al., 2004b), for examinations of climate-growth sensitivity (Pohtila, 1980; Lindholm, 1996; Timonen, 2001; Helama et al., 2004a) and in order to reconstruct the past climate variability (Lindholm, 1996; Lindholm \& Eronen, 2000; Helama et al., 2010). The aim of this study was to examine the statistical characteristics of the data, i.e. the timberline tree-ring series from a multitude of trees and sites, in order to hypothetically achieve improved quality and reliability of the resulting chronology.
In so doing, a simple screening of tree-ring series was performed according to the signal strength of the individual series. Since this is a region where the external signal of unmanaged pines is governed by mid-summer (July) temperature variability (Lindholm, 1996), the resulting tree-ring chronology was supposed to represent this signal. Assumingly, the results could have implications especially in the context of dendroclimatic (Fritts, 1976) interpretations of the tree-ring data in any region.

\section{Material and Methods}

\section{Sites and samples}

Tree-ring samples were cored by an increment borer at breast height from living Scots pine (Pinus sylvestris L.) trees in the protection forest area (Pohtila \& Timonen, 1980) of northern Finnish Lapland. Altogether 500 trees of different ages were cored in nine naturally grown sites in late autumn (Table 1). Two-hundred-forty-three pines were cored in 2007 and 257 pines in 2008. The forest site type of all the studied sites represented dry forest land. The ringwidths were measured from each core sample to the nearest one-hundredth of a millimeter under light-microscope, the series of tree-ring widths becoming simultaneously integrated into the computerized system.

Table 1. A list of tree-ring sampling sites with their geographical coordinates.

\begin{tabular}{lccc}
\hline Site name & Latitude & Longitude & Altitude \\
\hline Angeli & $68^{\circ} 54^{\prime} \mathrm{N}$ & $25^{\circ} 44^{\prime} \mathrm{E}$ & 285 \\
Hetta & $68^{\circ} 28^{\prime} \mathrm{N}$ & $23^{\circ} 24^{\prime} \mathrm{E}$ & 363 \\
Iijärvi & $69^{\circ} 17^{\prime} \mathrm{N}$ & $27^{\circ} 29^{\prime} \mathrm{E}$ & 222 \\
Kuttanen & $68^{\circ} 25^{\prime} \mathrm{N}$ & $22^{\circ} 49^{\prime} \mathrm{E}$ & 347 \\
Muotka & $69^{\circ} 12^{\prime} \mathrm{N}$ & $26^{\circ} 55^{\prime} \mathrm{E}$ & 253 \\
Pulju & $68^{\circ} 21^{\prime} \mathrm{N}$ & $24^{\circ} 40^{\prime} \mathrm{E}$ & 373 \\
Riekkovaara & $68^{\circ} 28^{\prime} \mathrm{N}$ & $27^{\circ} 18^{\prime} \mathrm{E}$ & 269 \\
Sevetti & $69^{\circ} 31^{\prime} \mathrm{N}$ & $28^{\circ} 33^{\prime} \mathrm{E}$ & 122 \\
Tämäkkä & $68^{\circ} 14^{\prime} \mathrm{N}$ & $26^{\circ} 22^{\prime} \mathrm{E}$ & 329 \\
\hline
\end{tabular}




\section{Detrending the series}

A negative exponential curve or a linear regression line with a negative slope or line through the series mean were fitted to the measurement series, and indices were derived from the curve by division. Using the formula of Fritts et al. (1969), a negative exponential curve can be modeled as follows:

$$
y=a e^{-b x}+d \quad \text { Eq. (1) }
$$

where $a$ and $d$ determined the initial and terminal heights of the curve and $b$ controlled its concavity. The curve model parameterization was done individually for each series using ARSTAN freeware (Holmes et al., 1986). The tree-ring index series were derived as ratios between the values of the observed and modeled values. The curve fitting approach was conservative, expected to account for the general decrease in ring-width as the pines age. Albeit detrending eliminates a portion of the longtime growth variations, the tree-ring indices were supposed containing considerable amount of corresponding growth variations due to chosen detrending method, as shown in previous studies in the study region (Lindholm, 1996; Helama et al., 2004b).

\section{Tree-ring statistics}

The tree-ring series were evaluated on the strength of their common growth signal. This was done using the correlation between each sample and the mean series of all other samples (that is, the master chronology) using the commonly exploited COFECHA freeware (Holmes, 1983; Grissino-Mayer, 2001). This correlation was computed as the Pearson product-moment correlation coefficient, thus measuring the linear relationship between the sample series and the master chronology. Hereafter, this measure is denoted as $R_{\text {master }}$.

Another statistics used to quantify the growth characteristics were the first order autocorrelation, standard deviation and mean sensitivity $(M S)$. This was deter- mined by Fritts (1976) as follows:

$$
M S=\frac{1}{n-1} \sum_{t=1}^{n-1}\left|\frac{2\left(x_{t+1}-x_{t}\right)}{x_{t+1}+x_{t}}\right|
$$

where $x$ is the tree-ring index of year $t$ in the series possessing $n$ tree-rings. $M S$ is a measure of the variation between consecutive years thus portraying the growth variability at inter-annual time-scales. The higher (lower) estimates of MS indicate larger (diminished) growth amplitudes. Compared to standard deviation, mean sensitivity is a measure of the variation between consecutive years (i.e., variability at inter-annual time-scales).

\section{Stripping the chronology}

The initial sample size was 500 tree-ring series. The number of tree-ring series constituting the chronology was reduced in step-wise fashion thus stripping the chronology. The criterion for this assorting was the Pearson correlation coefficient between the individual samples series and the master chronology (denoted here as $R_{\text {master }}$ ). In so doing, the threshold values for stripping were $0.2,0.3-0.8$. Thus, we obtained seven sets of tree-ring series, each containing limited data with remaining samples possessing $R_{\text {master }}$ above the corresponding threshold. Thus, the series with $R_{\text {master }}$ $>0.2$ entered the further analyses. This process was aided by KINDATA software of Timonen (2002).

\section{Characterizing the resulting chronologies}

The seven chronologies with differing $R_{\text {master }}$ thresholds were compared using Pearson correlation between the chronologies and between the chronology and climate data. In this case, the mean temperature of July (1908-2007) was used as measured at the weather station of Sodankylä $\left(67^{\circ} 22^{\prime} \mathrm{N} ; 26^{\circ}\right.$ $39^{\prime} \mathrm{E} ; 179 \mathrm{~m}$ a.s.1.) (Tuomenvirta et al., 2001) in central Lapland. Moreover, the chronologies were evaluated by the number of remaining samples and representing sites, first order autocorrelation, standard deviation, mean sensitivity (Eq. 2) and growth anomalies. 


\section{Results}

\section{Evocation of the data}

Overall, the sample contained 66667 measurements of ring-widths. The median and mean lengths of the sample series were around 120 and 130 years, respectively (Table 2). The youngest and oldest pines, at the occurrence of coring, had 24 and 440 rings, respectively. Roughly ninety percent $(87 \%)$ of the sample series covered the past 50 years (here, 1958-2007). We thus used this period as the common period for comparisons between the individual tree-ring series and, similarly, as the late calibration period for comparisons between the treering and meteorological data. Accordingly, the early calibration period was set as the 50-year interval preceding the late calibration period, thus covering the years 1908-1957.

\section{Detrended tree-ring series}

On an average, the tree-ring sample series correlated positively with each other and with summer temperatures (Table 2). The measures of variability, the standard deviation and mean sensitivity, were around 0.25 and 0.20 , indicating considerable vigor of growth variations at multiple timescales. Moreover, the series remained serially correlated as indicated by the first order autocorrelation (Table 2).

The statistics did however show marked differences from series to series. The differ-

Table 2. Characterization (1958-2007) of the treering series entering the analyses. The statistics included the strengths of growth correlativity to summer temperature $\left(R_{\text {July }}\right)$ and between the sample series and the master chronology $\left(R_{\text {master }}\right)$, standard deviation (SD), mean sensitivity (MS; Eq. 2), the first order autocorrelation (AR1) and the temporal length of the series.

\begin{tabular}{lcccccc}
\hline & $R_{\text {master }}$ & $R_{\text {July }}$ & SD & MS & AR1 & Length \\
\hline Median & 0.464 & 0.244 & 0.248 & 0.191 & 0.527 & 118.0 \\
Average & 0.465 & 0.233 & 0.266 & 0.195 & 0.514 & 130.4 \\
\hline
\end{tabular}

ences in $R_{\text {master }}$ could be partly explained by the correlativity of the growth variations to the variations in the summer temperatures (Fig. 1). The differences in $R_{\text {master }}$ could additionally be linked with the amplitudes of growth variations as quantified by standard deviations (Fig. 2a) but not with mean sensitivities (Fig. 2b). That is, the values of $R_{\text {master }}$ correlated statistically significantly and negatively with the former meanwhile no meaningful correlation was detected between the $R_{\text {master }}$ and the latter.

Also, the autocorrelation of the sample series could be associated with its common signal strength (Fig. 2c). Overall, the series owing high autocorrelations tended to show low values of $R_{\text {master }}$ The age of the sample tree did not appear to have any influence on its correlativity to the master chronology (Fig. 2d). These relationships (Figs. 1 and 2) were highly similar whether computed using Pearson product-moment or Spearman's rank correlation coefficient.

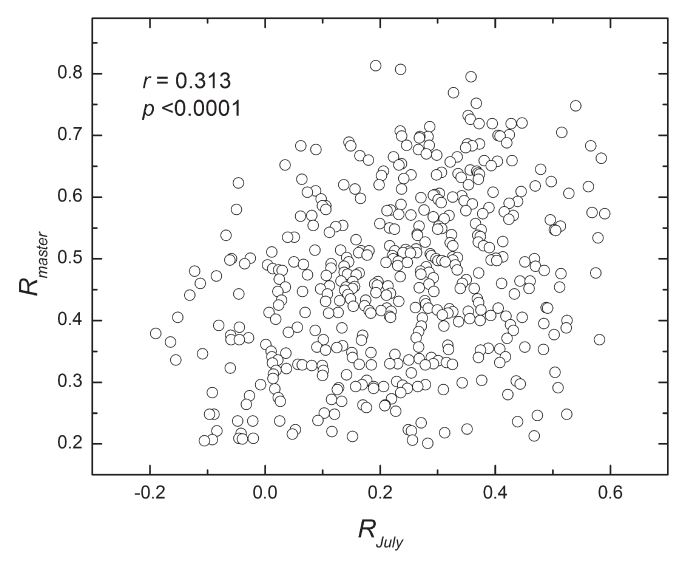

Figure 1. Association between the strengths of growth correlativity to summer temperature $\left(R_{\text {July }}\right)$ and between the sample series and the master chronology $\left(R_{\text {master }}\right)$, as calculated from the dataset of tree-ring series over the common period (1958-2007). Association was quantified using Pearson correlations $(r)$. 
(a)
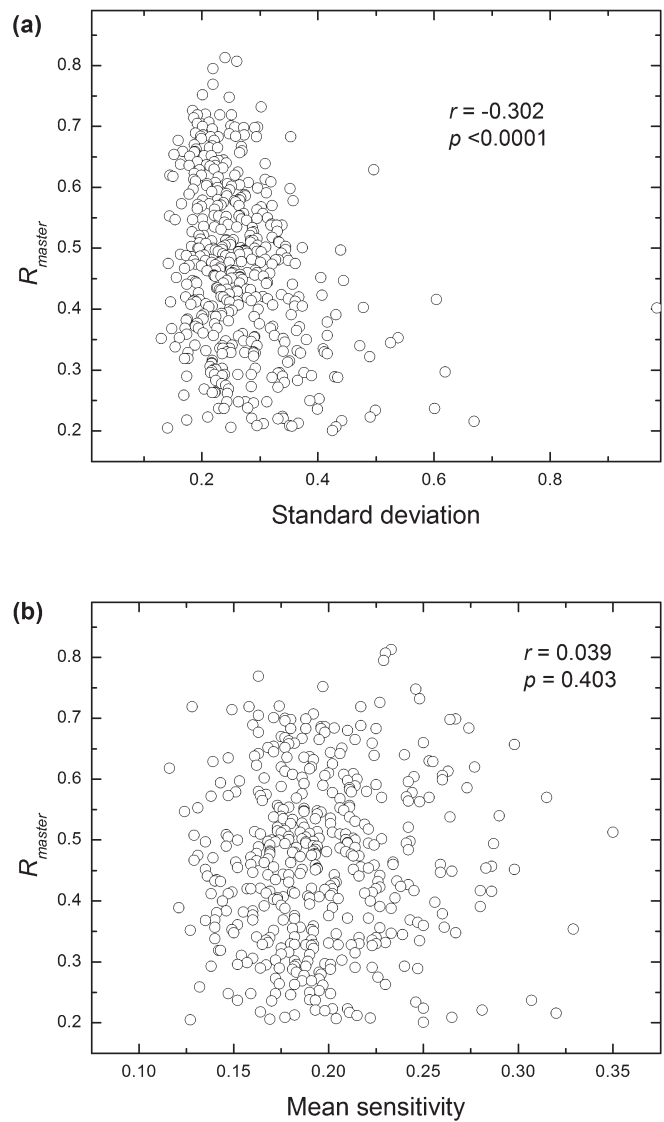

(c)

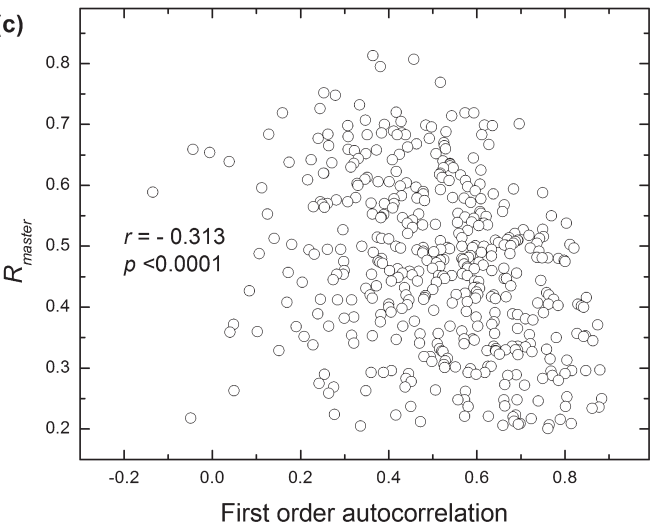

(d)

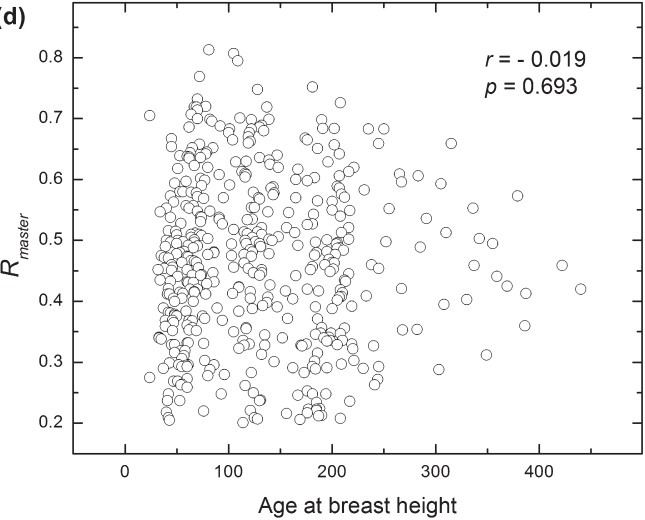

Figure 2. Association between the sample-to-master correlativity $\left(R_{\text {master }}\right)$ and different tree-ring statistics, as calculated from the dataset of sample series over the common period (1958-2007). Associations were quantified using Pearson correlations $(r)$.

\section{Averaged tree-ring chronologies}

The seven chronologies with raising $R_{\text {master }}$ thresholds showed declines in sample size (Figs. 3 and 4a). Accordingly, the number of sites declined, but not until the implementation of the two highest thresholds of $R_{\text {master }}$ (Fig. $4 \mathrm{a}$ ). In addition, the chronologies resulting from higher $R_{\text {master }}$ thresholds exhibited ampler index variations as seen visually (Fig. 5) and indicated both by standard deviations and mean sensitivities (Fig. 4b). In visual inspection, the crests and troughs of the growth were muted for chronologies with lower $R_{\text {master }}$ thresholds and vice versa.
Yet, the chronologies with raising $R_{\text {master }}$ thresholds showed elevating serial correlations. Moreover, the ascent of $R_{\text {master }}$ threshold lowered the correlativity of the resulting tree-ring chronology to summer temperatures (Fig. 6). All these changes appeared systematic and thus clear. Moreover, the aforementioned changes appeared timeindependent since the tendencies were parallel regardless of the study interval and whether it be the full (here 1908-2007; Figs. 4 \& 5), early (here 1908-1957; not shown) or late (here 1958-2007; not shown) period. There was however no similarly clear tendency with regards to the tree age. The ages 


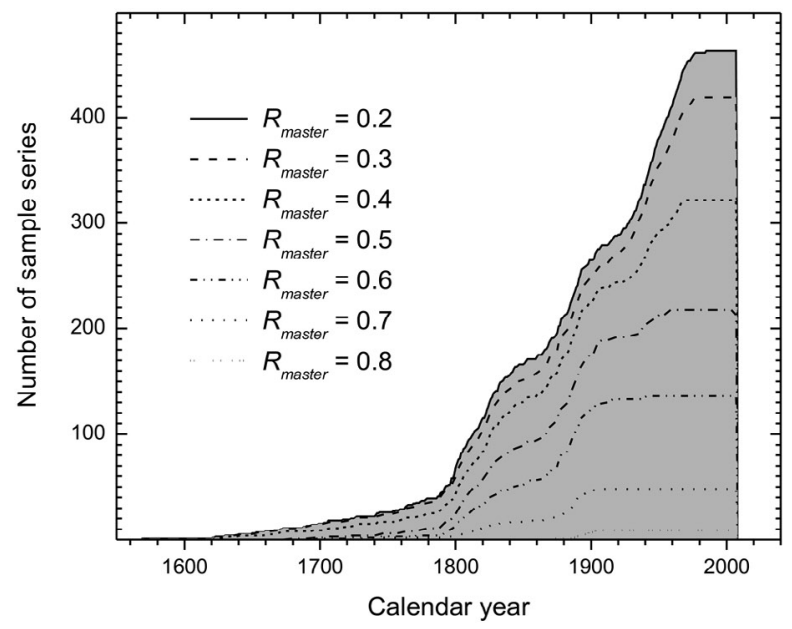

Figure 3. Time-dependent changes in the sample size of the seven chronologies with differing thresholds of $R_{\text {master }}$.

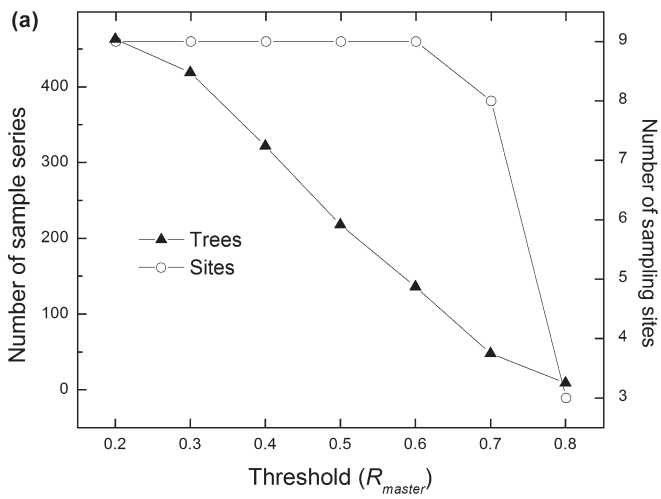

(c)
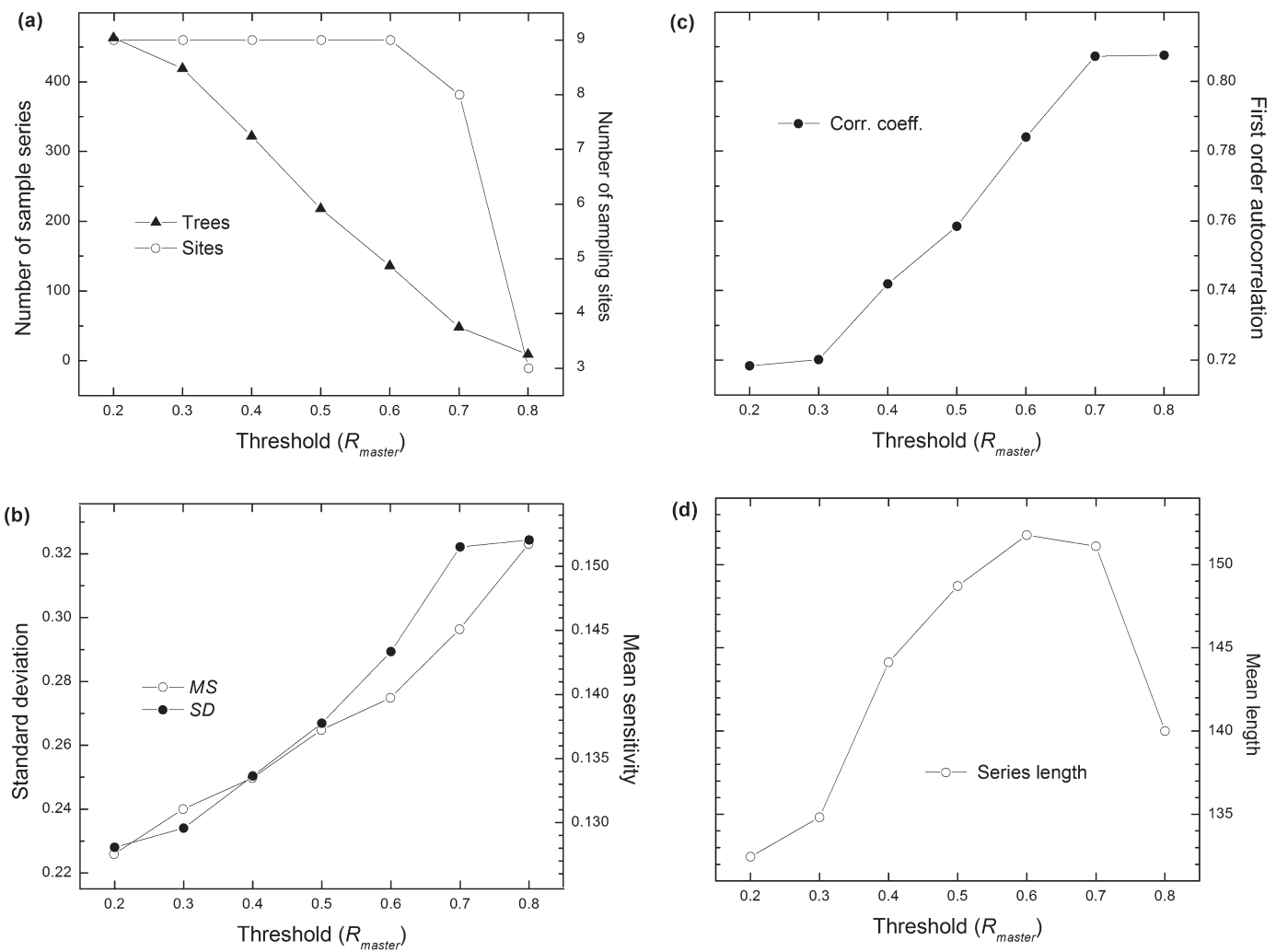

(d)

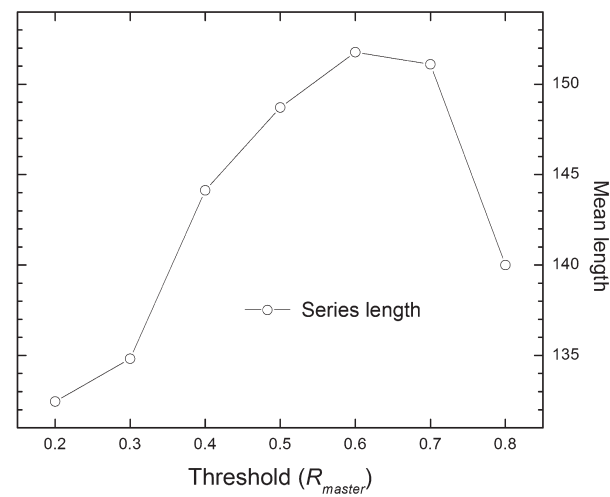

Figure 4. Tendencies in the tree-ring statistics for the resulting mean chronologies with differing thresholds of $R_{\text {master }}$ calculated for the full calibration period (1908-2007). 

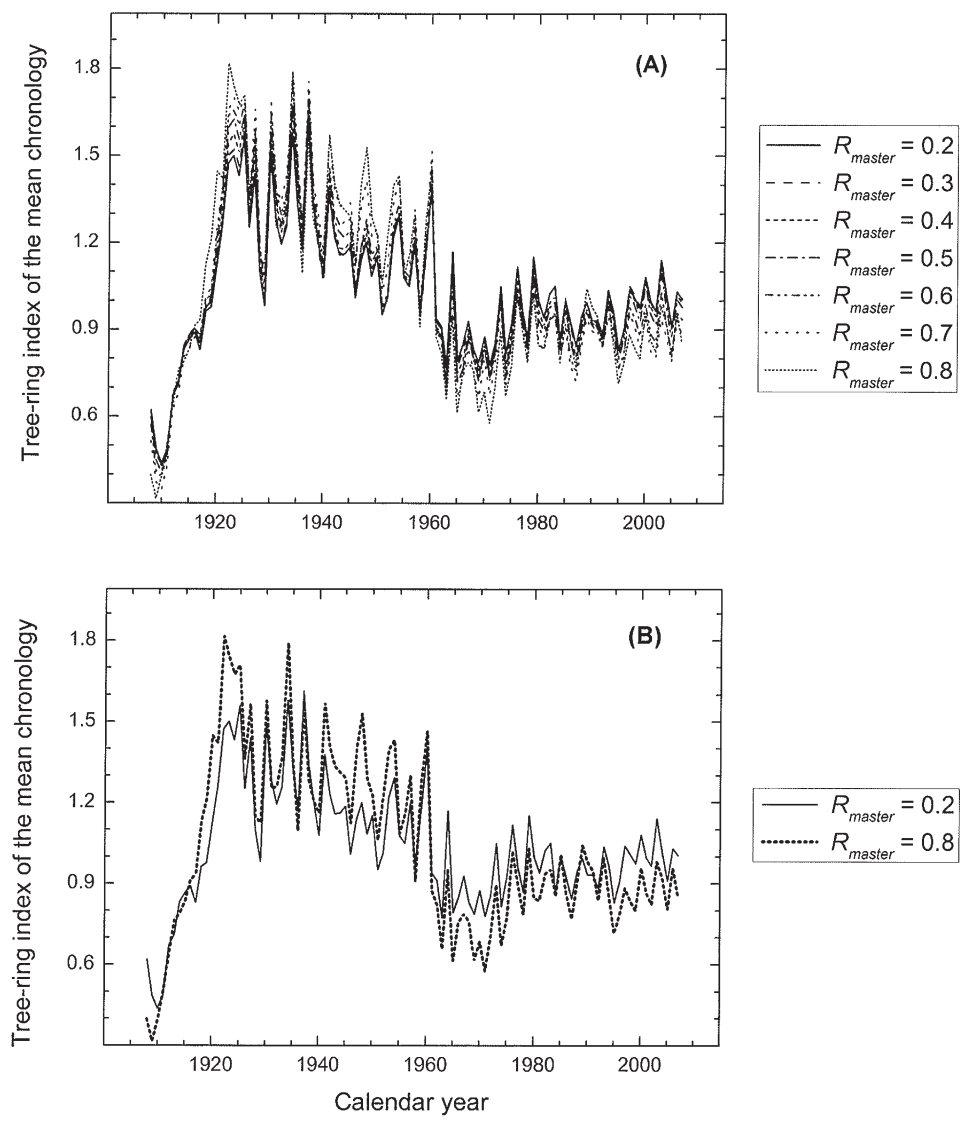

Figure 5. The mean chronologies with the seven differing thresholds of $R_{\text {master }}(\mathrm{a})$. The chronologies produced using lowest and highest $R_{\text {master }}$ thresholds showed muted and intensified growth amplitudes, respectively (b), over the full period (1908-2007).

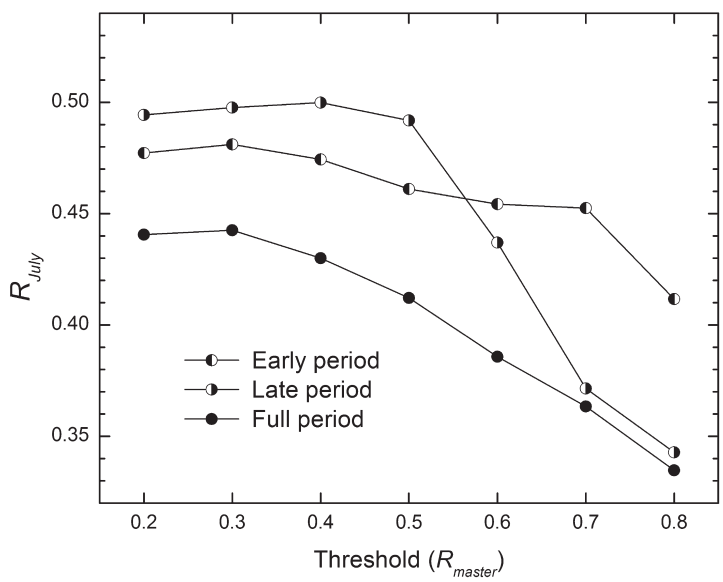

Figure 6. Declining strength of growth correlativity to summer temperature $\left(R_{\text {July }}\right)$ with elevated thresholds of $R_{\text {master, }}$ calculated for the early (1908-1957), late (1958-2007) and full (1908-2007) calibration periods. 
averaged highest with the threshold of $R_{\text {master }}$ $=0.6$, whereas lower mean ages were found for both lower and higher thresholds.

\section{Discussion}

Our dendroclimatic results agreed to show that the tree-ring growth in the region of Finnish Lapland is related to summer temperature variability (Fig. 1). This relationship between the climate and pine growth has been described as spatially as well as temporally the most stable climate signal in tree-ring data (Lindholm, 1996; Helama et al., 2004a). Further examination of the data revealed however a hitherto undescribed dilemma between the dendrochronological and dendroclimatic correlations. While it was found that the trees with higher sensitivity to this temperature control were more prone to correlate better with the master chronology (Fig. 1), the selection of the trees with the highest $R_{\text {master }}$ did not produce a new chronology with higher climate correlativity (Fig. 6). Actually, the sample size of the chronology was seen as a more important criterion for this dendroclimatic association as it became clear that the mean tree-ring chronology including the highest number of trees correlated best with the pre-determined climate variable of mid-summer temperature. Furthermore, this finding appeared time-independent (Fig. 6). In other words, it was not possible to find better-responding group of trees by the criterion of $R_{\text {master }}$ as used here and we remain to comprehend the data selection inherent to the cross-dating procedure (e.g. Douglass, 1941; Stokes \& Smiley, 1968; Yamaguchi, 1991) as the primary screening of the series representing the common signal in the growth.

The results of this study compare with those presented previously for a 15-site dataset of Agathis australis tree-ring example from New Zealand (Fowler \& Boswijk, 2003). Albeit their chronology stripping statistics were somewhat different to ours, the both methods were principally based on linear correlativity between the treering width series. The results from the Agathis australis tree-ring study suggested that modest benefits could be obtained by stripping the chronology by omitting the sub-optimal samples from the chronology (Fowler \& Boswijk, 2003). Combined with our findings, the results could revert to the principal dendrochronological theory that the replication enhances the climate signal in tree-ring chronologies (Fritts, 1976).

In the same context, the results shown here demonstrated the efficiency of the mean chronology to enhance the common signal in tree-ring growth. Also, the same has previously been shown to apply to instrumental climate records as the regionally averaged climate outperformed singlestation data in dendroclimatic comparisons (Blasing et al., 1981). In the context of treerings, on the other hand, one reason for this enhancement could be that the individual trees may represent the common growth signal invariably over different years. Such an instability has been described in previous studies (Riitters, 1990; Fowler \& Boswijk, 2003; Carrer, 2011). With these regards, a recent dendroecological study indicated even an overestimation in the real species responsiveness to climate variability by the mean chronology in comparison to individual trees (Carrer, 2011). In that study, the mean responses above the highest individual dendroclimatic correlations were revealed, these findings indicating an artificial inflation to the manifestation of the common signal (Carrer, 2011). That is, in real world no mean chronology is reacting to climatic changes but the individual trees respond. Also in our data, the correlation between the climate and the tree-ring chronologies (Fig. 6) were higher than the correlations of the individuals on an average (Table 2). However, we did not find indications for at least such a clear inflation in the present dataset as the highest individualistic responses (see $R_{\text {July }}$ in Fig. 1) were well above the mean responses (see $R_{\text {July }}$ in Fig. 6). 
Thus, the results indicate that an enhanced and static growth signal is attained by averaging high number of sample series into the mean chronology. That is, the results emphasized the efficiency of this method for studies where the main objective is the transfer of dendroclimatic functions for reconstructions of past conditions (Carrer, 2011). Indeed, the tree-rings of Scots pine have been used in the study region as indicators of the past climate variability. Likewise, the results of the present study have thus shown how these studies have advantaged from the proposed approach of averaging a high number of cross-dated samples (Lindholm, 1996; Lindholm \& Eronen, 2000; Helama et al., 2010).

A recent tree-ring study encouraged for comparing the behaviour between the individualistic and mean chronology timeseries (Carrer, 2011). Here, the statistics of the sample series (Fig. 2) and the mean chronology (Fig. 4) showed contrasting outcomes. Particularly, it was seen that the individual trees were characterized by negative correlation between their $R_{\text {master }}$ status and both the standard deviation (Fig. 2a) and the autocorrelation (Fig. 2c). By contrast, the averaging of trees with high $R_{\text {master }}$ resulted in mean chronologies with increasingly high standard deviations (Fig. 4b) and uplifted level of autocorrelation (Fig. 4c). In other words, the mean chronologies did not act as straightforward summaries of their constitute series. That the standard deviations, as well as the mean sensitivities (Fig. $4 b)$, were elevated by the increased restriction could actually be seen as a side effect from the inherent property of any treering chronology to portray increased variance as result from decreasing sample size (Osborn et al., 1997).

The issue of autocorrelation may also be viewed in the context of dendrochronological theory. In principle, the positive autocorrelation indicate dependence of treering formation on biological processes within the tree (Fritts, 1976). In fact, the level of tree-ring autocorrelation is control- led not only via climate-growth relationships but also by canopy dynamics disturbance factors, reproductive strategy and the detrending methods (Biondi \& Swetnam, 1987; Brienen et al., 2006). While the lattermost issue could be disregarded here as all the series were detrended using the same approach, the other issues could be seen valid for explaining the negative correlation at individual (Fig. 2c) but positive at mean (Fig. 4c) level. First, it could be stated that the individual trees with less biological control on their growth showed highest $R_{\text {master }}$ (Fig. 2c), the increase in $R_{\text {master }}$ in turn supposed to indicate high climatic control (Fig. 1). Second, the first order autocorrelation is known to indicate increased low-frequency (long-term) variability in tree-ring chronology (Cook \& Briffa, 1990; Helama et al., 2004b). The evidence for this is clearly produced as the mean chronologies with elevated $R_{\text {master }}$ threshold criteria portrayed more ample long-term fluctuations (Fig. 5). As previously alluded to, the increased long-term growth amplitudes may have statistically resulted from the decrease in the sample size. In the same context, it is worth to note that the consistent increase in the autocorrelation of the mean chronology (Fig. 4c) may have influenced the simultaneous degradation of the climate-sensitivity of the chronology (Fig. 6). This becomes logic as the increased autocorrelation indicates increased biological (i.e., non-climatic) origin of tree-ring variability. Indeed, the tree-ring data is primarily biological information and it is known (e.g. Helama et al., 2009) that the autocorrelations of Scots pine tree-rings in the study region are typically higher than those of climate data.

\section{Conclusions}

This study dealt with the idea of dendrochronological data selection. In so doing, we have realized several contrasting features of tree-ring data at individualistic and mean level. It was found that the screening of the data may alter the chronology varia- 
tions. Statistical interpretation was needed to understand these alterations. Although the results were supported by a wide range of dendrochronological literature, it is worth emphasizing that chronology stripping may produce differing outcomes in the case of different initial datasets as well as different detrending methods. With our data, the dendroclimatic signal was found weakened at mean level as the sample size decreased (this decrease seen to occur through the reduction of sampled trees and sampling sites), despite of higher dendrochronological signal of the remaining trees at individual level. Moreover, the mean chronology showed elevated variance and autocorrelation with reduction in sample size, although it was known that at individual level the remaining trees exhibited an opposite tendency. The researchers should be aware of these consequences if selecting tree-ring data using any other way but cross-dating. With these regards, we note that the growth variations estimated by the mean chronology may differ notably from those of individual sample series constituting the chronology. In dendroecological context, the study of individual tree-ring series, in addition to the traditional analysis of mean chronologies, could be thus encouraged as future prospect. Studying the individual series is expected to enhance the understanding of tree responsiveness to environmental changes. With a potential exception of studies where the main objectives are reconstructions of past conditions, the dendrochronologists should be aware of the growth processes and their driving factors at both, individualistic and mean levels.

Acknowledgements. This study was supported by the Academy of Finland (\#251441). The fieldwork was supported by the grant from Metsämiesten Säätiö.

\section{References}

Biondi, F. 1999. Comparing tree-ring chronologies and repeated timber inventories as forest monitoring tools. - Ecological Applications, 9, 216-227.

Biondi, F., Swetnam, T.W. 1987. Box-Jenkins models of forest interior tree-ring chronologies. - Tree Ring Bulletin, 47, 71-96.

Blasing, T.J., Duvick, D.N., West, D.C. 1981. Dendroclimatic calibration and verification using regionally averaged and single station precipitation data. - Tree-Ring Bulletin, 41, 37-43.

Brienen, R.J.W., Zuidema, P.A., During, H.J. 2006. Autocorrelated growth of tropical forest trees: Unraveling patterns and quantifying consequences. - Forest Ecology and Management, 237, 179-190.

Carrer, M. 2011. Individualistic and Time-Varying TreeRing Growth to Climate Sensitivity. - PLoS ONE 6(7): e22813. doi:10.1371/journal.pone.0022813.

Cook, E.R., Briffa, K.R. 1990. A comparison of some tree-ring standardization methods. - Cook, E., Kairiukstis, L. A. (eds.). Methods of dendrochronology: applications in the environmental science. Kluwer, Dordrecht, 153-162.

Cook, E.R., Shiyatov, S., Mazepa, V. 1990. Estimation of the mean chronology. - Cook, E., Kairiukstis, L.A. (eds.). Methods of dendrochronology: applications in the environmental science. Kluwer, Dordrecht, 123-132.

Douglass, A.E. 1941. Crossdating in dendrochronology. - Journal of Forestry, 39, 825-831.

Fowler, A., Boswijk, G. 2003. Chronology stripping as a tool for enhancing the statistical quality of tree-ring chronologies. - Tree-Ring Research, 59, 53-62.

Fritts, H.C. 1976. Tree rings and climate. Academic, London, $567 \mathrm{pp}$.

Fritts, H.C., Mosimann, J.E., Bottorff, C.P. 1969. A revised computer program for standardizing tree-ring series. - Tree-Ring Bulletin, 29, 15- 20.

Grissino-Mayer, H.D. 2001. Evaluating crossdating accuracy: A manual and tutorial for the computer program COFECHA. - Tree-Ring Research, 57, 205-221.

Helama, S., Holopainen, J., Timonen, M., Ogurtsov, M. G., Lindholm, M., Meriläinen, J., Eronen, M. 2004a. Comparison of living-tree and subfossil ringwidths with summer temperatures from 18th, 19th and 20th centuries in northern Finland. - Dendrochronologia, 21, 147-154.

Helama, S., Lindholm, M., Timonen, M., Eronen, M. 2004b. Detection of climate signal in dendrochronological data analysis: a comparison of treering standardization methods. - Theoretical and Applied Climatology, 79, 239-254.

Helama, S., Macias Fauria, M., Mielikäinen, K., Timonen, M., Eronen, M. 2010. Sub Milankovitch solar forcing of past climates: mid and late Holocene perspectives. - Geological Society of America Bulletin, 122, 1981-1988. 
Helama, S., Makarenko, N.G., Karimova, L.M., Kruglun, O.A., Timonen, M., Holopainen, J., Meriläinen, J., Eronen, M. 2009. Dendroclimatic transfer functions revisited: Little Ice Age and Medieval Warm Period summer temperatures reconstructed using artificial neural networks and linear algorithms. - Annales Geophysicae, 27, 1097-1111.

Helama, S., Salminen, H., Timonen, M., Varmola, M. 2008. Dendroclimatological analysis of seeded and thinned Scots pine (Pinus sylvestris L.) stands at the coniferous timberline. - New Forests, 35, 267-284.

Holmes, R.L. 1983. Computer-assisted quality control in tree-ring dating and measurement. - Tree-Ring Bulletin, 43, 69-75.

Holmes, R.L., Adams, R.K., Fritts, H.C. 1986. Treering chronologies of western North America: California, eastern Oregon and northern Great Basin, with procedures used in the chronology development work, including user manuals for computer programs COFECHA and ARSTAN. - Chronology Series VI. Laboratory of Tree-Ring Research, University of Arizona, Tuscon, 50-65.

Lamarche, V.C., Jr. 1982. Sampling strategies. - Hughes, M.K., Kelly, P.M., Pilcher, J.R., Lamarche, V.C., Jr. (eds.). Climate from tree rings. Cambridge University Press, Cambridge, 2-6.

Lindholm, M. 1996. Reconstruction of past climate from ring-width chronologies of Scots pine (Pinus sylvestris L.) at the northern forest limit in Fennoscandia. - University of Joensuu, Publications in Sciences, 40, 1-169.

Lindholm, M., Eronen, M. 2000. A reconstruction of mid-summer temperatures from ring-widths of Scots pine since AD 50 in northern Fennoscandia. - Geografiska Annaler, 82 A, 527- 535.

Lindholm, M., Lehtonen, H., Kolström, T., Meriläinen, J., Eronen, M., Timonen, M. 2000. Climatic signals extracted from ring-width chronologies of Scots pine from the northern, middle and southern parts of the boreal forest belt in Finland. - Silva Fennica, 34, 317-329.

Metsaranta, J.M., Lieffers, V.J. 2009. Using dendrochronology to obtain annual data for modeling stand development: a supplement to permanent sample plots. - Forestry, 82, 163-173.

Mielikäinen, K. Timonen, M. 1996. Growth trends of Scots pine (Pinus sylvestris, L.) in unmanaged and regularly managed stands in Southern and Central Finland. - Spiecker, H., Köhl, M., Mielikäinen, K., Skovsgaard, J.P. (eds.). Growth Trends in European Forests. European Forest Institute Research Report No. 5, European Forest Institute, 41-59.

Mikola, P. 1950. On the varitions in tree growth and their significance to growth studies. - Communicationes Instituti Forestalis Fenniae, 38, 1-131.
Osborn, T.J., Briffa, K.R., Jones, P.D. 1997. Adjusting variance for sample-size in tree-ring chronologies and other regional mean timeseries. - Dendrochronologia, 15, 89-99.

Peters, K., Jacoby, G.C., Cook, E.R. 1981. Principal components analysis of treering sites. - Tree Ring Bulletin, 41, 1-19.

Phipps, R.L. 1982. Comments on interpretation of climatic information from tree rings, eastern North America. - Tree-Ring Bulletin, 42, 11-22.

Pohtila, E. 1980. Climatic fluctuations and forestry in Lapland. - Holarctic Ecology, 3, 91-98.

Pohtila, E., Timonen, M. 1980. Scots pine plantations and their early development in the protection forests of Finnish Lapland. - Folia Forestalia, 453, 1-18.

Riitters, K. 1990. Analysis of biweight site chronologies: relative weights of individual trees over time. - Tree-Ring Bulletin, 50, 11-19.

Schweingruber, F.H., Kairiukstis, L., Shiyatov, S. 1990. Sample selection. - Cook, E., Kairiukstis, L. A. (eds.). Methods of dendrochronology: applications in the environmental science. Kluwer Academic Publishers, 23-35.

Spiecker, H. 2002. Tree rings and forest management in Europe. - Dendrochronologia, 20, 191-202.

Stokes, M.A., Smiley, T.L. 1968. An introduction to tree ring dating. University of Chicago Press, Chicago, 73 pp.

Timonen, M. 2001. Ilmaston muutokset kautta aikojen - onko menneisyys Lapin metrien tulevaisuuden peili? - The Finnish Forest Research Institute Research Papers, 803, 9-29.

Timonen, M. 2002 Lustotiedon tutkumusjärjestelmä KINSYS. - Tiedonanto 2/2000. Dendrokronologian laboratorio. Metsäntutkimuslaitos. Rovaniemen tutkimusasema. Rovaniemi, 1-39.

Tuomenvirta, H., Drebs, A., Førland, E., Tveito, O.E., Alexandersson, H., Laursen, E.V., Jónsson, T. 2001. Nordklim data set 1.0 - description and illustrations. - DNMI - REPORT 08/01. Norwegian Meteorological Institute, Oslo, 1-27.

Varmola, M., Salminen, H., Timonen, M. 2004. Thinning response and growth trends of seeded Scots pine stands at the arctic timberline. - Silva Fennica, 38, 71-83.

Wigley, T.M.L., Briffa, K.R., Jones, P.D. 1984. On the average value of correlated time series, with applications in dendroclimatology and hydrometeorology. - Journal of Climate and Applied Meteorology, 23, 201-213.

Yamaguchi, D.K. 1991. A simple method for crossdating increment cores from living trees. - Canadian Journal of Forest Research, 21, 414-416. 